\title{
Hubungan antara Self-Esteem dengan Strategi Coping Remaja yang mengalami Kekerasan Emosional masa Kanak
}

\author{
Geby Zelindra Meida \& Atika Dian Ariana* \\ Fakultas Psikologi Universitas Airlangga
}

\begin{abstract}
ABSTRAK
Kekerasan emosional pada masa kanak meninggalkan luka dan trauma yang mendalam bagi remaja yang mengalaminya. Kekerasan emosional dapat berdampak pada self-esteem remaja dan bagaimana strategi coping yang diterapkan remaja dalam menghadapi stressor. Self-Esteem menentukan apakah remaja merasa memiliki kemampuan untuk menghadapi stressor. Strategi coping yang efektif berhubungan dengan sikap adaptif terhadap stressor dan kesehatan mental. Penelitian ini bertujuan untuk mengetahui hubungan antara self-esteem dengan strategi coping remaja yang mengalami kekerasan emosional masa kanak. Penelitian ini menggunakan metode kuantitatif dan dilakukan pada 76 partisipan berusia 12-21 tahun. Alat ukur yang digunakan adalah BRIEF Cope dan Rosenberg SelfEsteem Scale (RSES). Hasil penelitian menunjukkan bahwa self-esteem dan strategi coping memiliki hubungan yang signifikan dan positif pada remaja yang mengalami kekerasan emosional masa kanak. Hubungan yang positif berarti semakin tinggi self-esteem remaja maka semakin efektif strategi coping yang diterapkan remaja korban kekerasan emosional masa kanak.
\end{abstract}

Kata kunci: kekerasan emosional masa kanak, remaja, self-esteem, strategi coping

\begin{abstract}
Childhood Emotional Abuse leave deep scars and trauma for adolescents who experience it. Emotional abuse can impact on adolescent self-esteem and what type of coping strategies applied by adolescents in dealing with stressors. Self-Esteem determines whether adolescents feel they can deal with stressors. Effective coping strategies are associated with adaptive attitudes towards stressors and healthy mental. This study aims to determine the relationship between self-esteem and coping strategies among adolescents who experience childhood emotional abuse. This study used quantitative methods and was conducted on 76 participants aged 12-21 years. The measuring instruments used are BRIEF Cope and Rosenberg Self-Esteem Scale (RSES). The results showed that self-esteem and coping strategies had a significant and positive relationship in adolescents who experience childhood emotional abuse. A positive relationship means that the higher the self-esteem of adolescents, the more effective the coping strategies used by adolescents who are victims of childhood emotional abuse.
\end{abstract}

Keywords: adolescent, childhood emotional abuse, coping strategy, self-esteem

Buletin Penelitian Psikologi dan Kesehatan Mental (BRPKM), 2021, Vol. 1(2), 1132-1140

*Alamat korespondensi: Fakultas Psikologi Universitas Airlangga, Kampus B Universitas Airlangga Jalan Airlangga 4-6 Surabaya 60286. Surel: atika.ariana@psikologi.unair.ac.id

Naskah ini merupakan naskah dengan akses terbuka dibawah ketentuan the Creative Common Attribution License (CC-BY-4.0) (http://creativecommons.org/licenses/by/4.0), 
sehingga penggunaan, distribusi, reproduksi dalam media apapun atas artikel ini tidak dibatasi, selama sumber aslinya disitir dengan baik.

\section{PEN D A H U L UA N}

Remaja adalah fase transisi dalam kehidupan manusia dari masa kanak-kanak menuju dewasa, dimulai pada usia 12 tahun yang berakhir pada usia 18 hingga 22 tahun (Santrock, 2014). Pada masa ini, remaja cenderung mulai menghabiskan waktu diluar rumah bersama teman sebayanya dengan berbekal pada hal-hal yang sudah dipelajarinya selama masa kanak-kanak. Hal ini berkaitan dengan hubungan orang tua dan remaja, tak jarang remaja mengalami perlakuan yang tidak seharusnya atau kekerasan dalam rumah tangga pada masa kanak maupun hingga remaja.

Kekerasan rumah tangga dapat dikategorikan menjadi beberapa bentuk, yaitu kekerasan fisik, seksual, emosional dan penelantaran. Hornor (2012) menyatakan bahwa kekerasan rumah tangga dapat menyebabkan konsekuensi negatif seperti post-traumatic stress, depresi dan penyalahgunaan obat pada anak. Penelitian mengenai kekerasan seksual dan fisik pada anak banyak dilakukan dan dapat ditemui dengan mudah. Bentuk kekerasan fisik dan seksual pun dapat dilihat dengan jelas. Namun, pada kekerasan emosional, baik pelaku atau korban seringkali tidak menyadari karena bentuk dari kekerasan emosional tidak dapat dilihat bentuk fisiknya. Kementerian Pemberdayaan Perempuan dan Perlindungan Anak meluncurkan hasil Survei Nasional Pengalaman Hidup Anak dan Remaja tahun 2018 (SNPHAR 2018) dan hasil survei menunjukkan 1 dari 2 anak laki-laki dan 3 dari 5 anak perempuan pernah mengalami kekerasan emosional baik dengan prevalensi paling tinggi berada pada lingkungan rumah tangga (KemenPPPA, 2019).

Shapero dkk. (2014) melakukan penelitian mengenai kekerasan emosional dan fisik rumah tangga yang dialami remaja dan menunjukkan bahwa kekerasan emosional memiliki hubungan yang sangat kuat dengan status kesehatan mental yang lenih buruk daripada kekerasan fisik. Beberapa penelitian yang meneliti dampak dari pengalaman kekerasan emosional menunjukkan bahwa individu yang mengalami kekerasan emosional menunjukkan lebih banyak masalah emosional, termasuk depresi, kecenderungan bunuh diri, dan gangguan pascatrauma (Langevin dkk., 2015 dalam Arslan, 2015). Shaffer dkk. (2009) juga menemukan bahwa kekerasan emosional rumah tangga masa kanak memiliki dampak yang lebih signifikan pada perilaku penarikan diri remaja dari lingkungan sosialnya daripada jenis kekerasan lain.

Kekerasan emosional memuat perilaku mengkritik, menyalahkan, meremehkan, mengasingkan dan mengancam anak dalam situasi yang membahayakan (Carr, 2016). Korban yang mengalami kekerasan emosional dapat menumbuhkan perasaan tidak berharga, tidak dicintai dan tidak diinginkan dan perasaan ini dapat bertahan hingga usia remaja. Tingginya prevalensi kekerasan emosional rumah tangga menunjukkan bahwa sebagian besar kekerasan emosional justru dilakukan oleh anggota keluarga. Tindak kekerasan dalam keluarga terhadap anak banyak tidak terungkap pada publik karena masih ada beberapa anggapan bahwa tindak kekerasan pada anak menjadi urusan domestik keluarga yang tidak layak atau tabu untuk dipublikasikan (Naning, 2009 dalam Sari \& Putra, 2014).

Anak yang mengalami kekerasan emosional seringkali berkembang di lingkungan yang kurang dukungan sehingga cenderung merasa stres dan tertekan (Bell \& Belsky, 2007 dalam Cook dkk., 2012). Akibatnya, ketika anak berada pada fase remaja dan di hadapkan dengan stressor dalam lingkungan luar cenderung mengalami kesulitan mengatur emosi karena tidak memiliki gambaran bagaimana cara menghadapi tekanan atau stressor-nya (Obradovic, 2010 dalam Cook dkk., 2012). Perubahan yang dialami masa remaja juga memberikan tekanan pada remaja karena remaja harus beradaptasi dengan

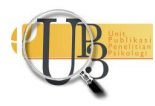


perubahan tersebut. Remaja masih bergantung pada orang tua mereka guna memenuhi kebutuhan hidup, sehingga remaja merasa tertekan karena tidak memiliki kekuatan atas perilaku kekerasan emosional yang dilakukan orang tua dan tidak dapat berbuat apa-apa, sehingga akhirnya remaja memilih menghindar dari situasi yang melibatkan orang tua (Gagné \& Melançon, 2013). Penghindaran ini merupakan strategi coping atau upaya remaja dalam mengatasi stressor akibat kekerasan emosional yang dialaminya.

Strategi coping sebagaimana dijelaskan oleh Lazarus \& Folkman (1984) adalah usaha individu untuk mengatasi ketidaksesuaian antara tuntutan dan kemampuan atau sumber daya yang mereka miliki dalam situasi yang dapat mengakibatkan stres. Setiap individu juga memiliki cara tersendiri untuk melakukan coping. Beberapa individu memilih untuk menghadapi situasi yang menyebabkan stres tersebut secara langsung atau merencanakan hal yang harus dilakukan untuk menghadapi situasi stres tersebut sedangkan beberapa individu memilih untuk menerima situasi tersebut dan menganggap situasi stres sebagai sesuatu yang positif atau bahkan menghindari situasi tersebut. Lazarus \& Folkman (1984) membedakan strategi coping menjadi dua jenis yaitu; problem-focused coping dan emotionfocused coping. Problem-focused coping adalah ketika individu fokus pada usaha untuk merubah atau mengurangi hal-hal yang mengakibatkan stres. Sedangkan emotion-focused coping adalah cara yang berfokus pada emosi individu tersebut.

Tan dkk. (2011) mengatakan coping yang efektif atau adaptif berarti kemampuan untuk menangani stresor secara efektif atau positif, sedangkan koping maladaptif atau tidak efektif berarti mengatasi stressor secara negatif atau tidak efektif. Remaja yang mengalami kekerasan emosional pada masa kanak-kanak, cenderung menerapkan penolakan sebagai strategi coping (Nguyen-Feng dkk., 2017). Remaja yang mengalami kekerasan emosional cenderung melakukan coping terhadap stresor sehariharinya dengan menyalahkan diri sendiri, menghindari orang lain dan berharap permasalahannya akan selesai dengan sendirinya (Nguyen-Feng dkk., 2017)

Taylor (2018) menjelaskan mengenai dua faktor yang berhubungan erat dengan strategi coping yaitu faktor eksternal dan internal. Faktor eksternal merupakan faktor dari luar seperti dukungan sosial, uang dan waktu. Faktor internal merupakan faktor yang berasal dari diri individu seperti metode coping yang biasa digunakan, tipe kepribadian dan self-esteem. Self-Esteem menurut Rosenberg (1965) dalam Mruk (2006) adalah evaluasi individu dari keseluruhan aspek mengenai dirinya sendiri.

Remaja yang memiliki self-esteem tinggi akan merasa mampu untuk mengatasi stresornya dan cenderung menggunakan strategi coping yang efektif seperti problem-focused coping agar stresor tersebut cepat berkurang (Chapman \& Mullis, 1999; Holahan \& Moos, 1987; Kammeyer-Mueller dkk., 2009 dalam Lee 2013). Selain itu, remaja dengan self-esteem yang tinggi akan merubah kondisi yang merupakan stresor karena individu dengan karakteristik ini cenderung memiliki kepercayaan bahwa mereka mampu untuk melakukannya dan tidak ragu.

Remaja memiliki tugas perkembangan kompleks yang mengharuskan mereka untuk lebih mandiri dalam menghadapi permasalahannya. Bagaimana remaja dapat mengatasi permasalahannya berhubungan dengan strategi coping dan evaluasi remaja mengenai dirinya, apakah remaja merasa mampu untuk menghadapi permasalahannya atau tidak. Self-Esteem yang rendah dan perasaan tidak berharga merupakan permasalahan yang paling umum dialami oleh remaja yang mengalami kekerasan emosional masa kanak (Nguyen-Feng dkk., 2017). dan berkaitan dengan strategi coping yang cenderung tidak efektif atau maladaptif. Keberhasilan penelitian ini diharapkan dapat digunakan secara praktis maupun teoritis terkait dengan masalah kekerasan emosional, strategi coping, self-esteem pada remaja. Berdasarkan uraian diatas, maka hipotesis penelitian ini adalah self-esteem memiliki hubungan dengan 
strategi coping remaja yang mengalami kekerasan emosional pada masa kanak. Tujuan dari penelitian ini adalah untuk mengetahui apakah terdapat hubungan antara self-esteem dengan strategi coping remaja yang mengalami kekerasan emosional pada masa kanak.

\section{Desain Penelitian}

\section{MET ODE}

Penelitian ini merupakan penelitian kuantitatif yang menggunakan teknik pengambilan sampel secara acak, menggunakan alat ukur atau instrument penelitian dan analisis data menggunakan metode statistic. Pemilihan tipe kuantitatif didasarkan pada tujuan penelitian yaitu menguji hipotesis dengan cara mendapatkan nilai signifikansi hubungan antar variabel. Desain penelitian kuantitatif ini menggunakan metode survei menggunakan kuesioner secara online. Penentuan desain ini didasarkan pada metode survei yang dapat mengkaji populasi yang besar dengan menggunakan sampel dari populasi guna membuat generalisasi yang berkaitan dengan karakteristik populasi tersebut.

\section{Partisipan}

Partisipan dalam penelitian ini adalah remaja yang mengalami kekerasan emosional pada masa kanak $(N=76,78,9$ persen perempuan). Penentuan partisipan penelitian ini menggunakan teknik sampling purposive dimana pemilihan sampel berdasarkan pada karakteristik tertentu dan sesuai dengan tujuan penelitian. Kriteria partisipan dalam penelitian ini terdiri dari: a.) Berusia 12-21 Tahun; b.) Mengalami kekerasan emosional pada masa kanak; c.) Bersedia menjadi partisipan penelitian. Adapun proses pengumpulan data dilakukan dengan online melalui google form yang terdiri dari biodata (nama/inisial, usia, laki-laki/perempuan) dan informed consent.

\section{Pengukuran}

Strategi Coping menurut Folkman \& Moskowitz (2004) adalah sebuah praktek kognitif dan perilaku yang terus berubah dan berkembang guna menangani tuntutan eksternal ataupun internal tertentu yang dianggap diluar kemampuan individu. Instrumen yang digunakan untuk mengukur strategi coping adalah skala BRIEF Cope yang dikembangkan oleh Carver dkk., (1989) berlandaskan pada teori coping klasik yang dikemukakan oleh Lazarus \& Folkman (1984). Skala ini terdiri dari 14 subskala yang sudah dikelompokkan menjadi dua tipe yaitu problem-focused coping (Active Coping, Planning, Instrumental Support dan Venting) dan emotion-focused coping (Self-Distraction, Denial, Substance Abuse, Emotional Support, Behavioral disengagement, Positive Reframing, Humor, Acceptance, Religion, Self-blame) dengan masing-masing subskala terdiri dari dua aitem sehingga total 28 aitem dengan 5 pilihan jawaban (1="sangat tidak setuju", 5="sangat setuju"). Skala BRIEF Cope telah diterjemahkan ke dalam Bahasa Indonesia oleh (Sandiana \& Oriza, 2018) dan dilakukan uji validitas dengan hasil berkisar antara 0,360,49 dan nilai reliabilitas dari uji coba terpakai $(N=76 ; \alpha=0,830)$ sehingga 28 aitem tersebut digunakan sepenuhnya pada penelitian ini.

Self-Esteem menurut Roosenberg (1965) dalam Mruk (2006) adalah evaluasi individu dari keseluruhan aspek mengenai dirinya sendiri. Instrumen yang digunakan untuk mengukur self-esteem adalah Rosenberg Self-Esteem Scale (RSES) yang ditranslasi (dari Bahasa Inggris ke Bahasa Indonesia) oleh Azwar (2019). Skala ini memiliki 10 aitem yang terdiri dari masing-masing 5 aitem favorable dan unfavorable dengan 5 pilihan jawaban (1="sangat tidak setuju", 5="sangat setuju"). Skala Self-Esteem yang telah diadaptasi oleh Azwar (2019) ini telah dilakukan uji validitas dengan hasil 0,703 dan nilai 
reliabilitas dari uji coba terpakai $(N=76 ; \alpha=0,892)$ sehingga sepuluh aitem tersebut digunakan sepenuhnya pada penelitian ini.

\section{Analisis Data}

Teknik analisis data yang digunakan untuk menguji hipotesis penelitian ini adalah teknik korelasi Spearman's rho karena data penelitian tidak memenuhi uji asumsi parametrik (normalitas dan linearitas). Selain itu, penulis juga melakukan alaisis tambahan pada salah satu variabel penelitian (selfesteem) dengan menggunakan uji Mann-Whitney Test untuk perbandingan dua kelompok guna mengetahui perbedaan skor self-esteem jika ditinjau berdasarkan durasi atau lamanya kekerasan emosional yang dialami remaja. Perangkat lunak yang digunakan untuk menganalisa data penelitian ini adalah SPSS 22 for Windows.

\section{HAS I L P E N EL I T I A N}

Hasil analisis deskriptif menunjukkan bahwa partisipan memiliki rata-rata skor self-esteem yang berada pada kategori sedang $(\mathrm{N}=76 ; \mathrm{M}=27,59 ; \mathrm{SD}=8,471)$, rata-rata skor strategi coping berada pada kategori sedang untuk strategi coping tipe problem-focused $(\mathrm{N}=76 ; \mathrm{M}=16,70 ; \mathrm{SD}=4,436)$ dan kategori sedang pada tipe emotion-focused ( $\mathrm{N}=76 ; \mathrm{M}=59,84 ; \mathrm{SD}=8,154)$.

Hasil analisis uji normalitas Kolmogrov-Smirnov menunjukkan bahwa kedua variabel tidak berdistribusi normal $(p<0,05)$. Data variabel strategi coping berdistribusi normal setelah ditinjau dari rasio kurtosis yang berada pada rentang -2 hingga 2 (rasio kurtosis strategi coping=-0,78), rasio kurtosis didapatkan dari perhitungan nilai statistic kurtosis dibagi dengan standar eror. Distribusi data variabel self-esteem tetap tidak normal apabila ditinjau dari rasio kurtosis, sehingga penulis melakukan transformasi data berdasarkan kemiringan distribusi data dengan rumus SQRT(x), namun data tersebut masih berdistribusi tidak normal. Hasil analisis uji linearitas menunjukkan bahwa nilai signifikansi antara variabel self-esteem dengan variabel strategi coping ( $p=0,732)$ memiliki hubungan yang linear $(p>0,05)$.

Berdasarkan hasil analisis uji korelasi, terdapat hubungan yang signifikan antara self-esteem dengan strategi coping $(\mathrm{r}(76)=0,257 ; p=0,025)$ dengan kekuatan hubungan yang lemah.

Hasil analisis tambahan menggunakan uji Mann-Whitney Test terkait dengan perbedaan skor self-esteem berdasarkan durasi kekerasan emosional yang dialami $(p=0,121>0,05)$ menunjukkan tidak terdapat perbedaan yang signifikan pada skor self-esteem antara remaja yang masih mengalami kekerasan emosional hingga remaja dan yang sudah tidak mengalami kekerasan emosional.

\section{I S K U S I}

Hasil analisis dalam penelitian ini menunjukkan bahwa terdapat hubungan yang signifikan antara kedua variabel (Self-Esteem dan Strategi Coping) pada remaja yang mengalami kekerasan emosional masa kanak, sehingga dapat disimpulkan bahwa $\mathrm{H}_{0}$ ditolak. Hubungan antar kedua variabel memiliki arah yang positif sehingga semakin tinggi self-esteem remaja yang mengalami kekerasan emosional masa kanak, maka semakin efektif strategi coping yang diterapkan dalam menghadapi stressor. Kekuatan hubungan antar kedua variabel cenderung lemah. Tidak ada perbedaan yang signifikan pada self-esteem ditinjau dari durasi kekerasan emosional yang dialami.

Hasil penelitian ini sejalan dengan temuan sebelumnya yang menunjukkan bahwa remaja yang mengalami kekerasan emosional pada masa kanak, cenderung menerapkan strategi coping yang tidak

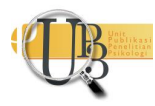


efektif yaitu penolakan terhadap stressor yang merupakan salah satu contoh dari penerapan emotionfocused coping sebagai strategi coping (Nguyen-Feng dkk., 2017). Selain itu, remaja yang mengalami kekerasan emosional masa kanak juga cenderung menerapkan strategi coping yang kurang efektif seperti cenderung menyalahkan diri sendiri, menghindari orang lain dan berharap permasalahannya akan selesai dengan sendirinya (Nguyen-Feng dkk., 2017). Strategi coping dengan menghindari permasalahan berkaitan erat dengan peningkatan masalah perilaku remaja dan kesehatan mental (Gagne \& Melancon, 2012). Remaja dengan self-esteem rendah mengandalkan strategi berbasis emosi (misalnya, menghindari tekanan) dalam mengatasi, sedangkan remaja dengan harga diri tinggi mengandalkan strategi yang diarahkan pada pemecahan masalah (Mullis \& Chapman, 2000).

Kekerasan emosional yang dialami remaja masa kanak juga ditemukan berhubungan secara negatif dengan jenis strategi coping, dukungan sosial dan self-esteem remaja. Penelitian yang dilakukan Wang dkk. (2020) menunjukkan bahwa remaja yang mengalami kekerasan emosional masa kanak cenderung menerapkan strategi coping yang negatif atau tidak efektif, self-esteem yang rendah dan terus menurun secara signifikan dan merasa tidak berhak dan pantas untuk mendapatkan dukungan sosial dari orang sekitarnya.

Berbeda dengan penelitian yang dilakukan oleh Ilahi \& Hartini (2015) mengenai hubungan antara selfesteem dengan strategi coping remaja akhir yang mengalami perceraian orang tua. Penelitian tersebut menunjukkan bahwa tidak terdapat hubungan antara self-esteem dengan strategi coping pada remaja akhir yang mengalami perceraian orang tua secara umum, namun terdapat hubungan yang lemah pada self-esteem dan strategi coping dengan tipe emotion-focused coping.

Hasil penelitian ini yang menunjukkan lemahnya hubungan antar kedua variabel dikarenakan terdapat beberapa faktor lain yang mempengaruhi yang dapat menjadi variabel mediator ataupun moderator antara kedua variabel tersebut. Arslan (2015) melakukan penelitian untuk mengetahui hubungan kekerasan emosional dengan permasalahan emosi dan perilaku dengan self-esteem sebagai variabel mediator. Penelitian tersebut menunjukkan bahwa dukungan sosial dan bantuan dari orang-orang sekitar remaja juga dapat mempengaruhi self-esteem remaja yang mengalami kekersan emosional pada masa kanak. Penelitian tersebut juga menunjukkan bahwa kekerasan emosional yang dialami remaja akan mempengaruhi self-esteem tanpa memandang bentuk dan durasi kekerasan emosional yang dialami. Hal ini, sejalan dengan hasil analisis tambahan yang menunjukkan bahwa kekerasan emosional sama besar dampaknya pada setiap remaja yang mengalaminya, tidak memandang apakah kekerasan emosional terjadi dalam jangka waktu yang panjang dari kecil hingga remaja atau dalam jangka waktu yang singkat. Selain itu, Friedlander dkk. (2007, dalam Lee dkk. 2013) juga menemukan bahwa dukungan sosial dari teman sebaya adalah faktor yang penting sebagai mediator self-esteem pada anakanak dan remaja,

\section{S I M P U L A N}

Berdasarkan hasil penelitian ini dapat disimpulkan bahwa terdapat hubungan antara self-esteem dengan strategi coping remaja yang mengalami kekerasan emosional pada masa kanak. Arah hubungan antara self-esteem dengan strategi coping menunjukkan arah yang positif dimana menunjukkan bahwa semakin tinggi self-esteem remaja yang mengalami kekerasan emosional masa kanak, maka semakin efektif pula strategi coping yang akan diterapkannya ketika menghadapi tekanan atau stressor. Penelitian ini juga menunjukkan bahwa kekerasan emosional dapat mempengaruhi self-esteem remaja terlepas dari durasi atau lamanya kekerasan emosional yang dialami. 
Penulis menyadari beberapa keterbatasan yang dimiliki selama pelaksanaan penelitian ini. Oleh karena itu, penulis mengajukan beberapa saran untuk penelitian selanjutnya yang serupa untuk dapat menentukan variabel lainnya yang diprediksi berhubungan dengan strategi coping sehingga dapat memperkaya kajian mengenai strategi coping pada remaja yang mengalami kekerasan emosional pada masa kanak dilingkup yang lebih luas, bukan hanya dilingkungan rumah tangga. Penelitian berikutnya juga dapat melakukan analisis tambahan yang tidak dilakukan pada penelitian ini, seperti melakukan analisis perbedaan dari jenis kekerasan emosional yang dialami. Penulis selanjutnya juga disarankan untuk menggunakan rentang usia partisipan yang lebih spesifik, seperti remaja awal atau akhir guna meminimalisir variabel lain yang dapat mempengaruhi hasil penelitian. Selain itu, penulis juga menyarankan remaja untuk berlatih menerapkan strategi coping yang lebih efektif dalam menghadapi tekanan yang dihadapinya dan mencari dukungan dari orang lain yang dapat membantu meningkatkan kepercayaan dirinya dan membawa pengaruh positif terhadap remaja. Penulis juga mengajukan saran kepada pihak keluarga untuk dapat menciptakan suasana di rumah yang nyaman, penuh kasih sayang dan memberikan dukungan penuh kepada remaja.

\section{U C A P A N T E R I MAKASIH}

Penulis mengucapkan terima kasih kepada Tuhan Yang Maha Esa atas segala rahmat dan nikmat yang telah diberikan kepada penulis, kepada dosen pembimbing penulis yaitu Atika Dian Ariana S.Psi., M.Sc., kepada orang tua penulis serta kepada seluruh partisipan yang telah bersedia untuk membantu penelitian ini.

\section{DEKLARAS I POTENSI TERJADINYA KONFLIK KEPENTINGAN}

Geby Zelindra Media dan Atika Dian Ariana tidak bekerja, menjadi konsultan, memiliki saham, atau menerima dana dari perusahaan atau organisasi manapun yang mungkin akan mengambil untung dari diterbitkannya naskah ini.

\section{PUSTAKA ACUAN}

Arslan, G. (2015). Psychological maltreatment, emotional and behavioral problems in adolescents: The mediating role of resilience and self-esteem. Child Abuse \& Neglect, 52, 200-209. https://doi.org/10.1016/j.chiabu.2015.09.010

Azwar, A. (2019). Penyusunan Skala Psikologi (Edisi 2). Pustaka Pelajar.

Carr, A. (2016). The handbook of child and adolescent clinical psychology: A contextual approach (Third edition). Routledge, Taylor \& Francis Group.

Carver, C. S., Scheier, M. F., \& Weintraub, J. K. (1989). Assessing coping strategies: A theoretically based approach. Journal of Personality and Social Psychology, 56(2), 267-283. https://doi.org/10.1037/0022-3514.56.2.267

Cook, E. C., Chaplin, T. M., Sinha, R., Tebes, J. K., \& Mayes, L. C. (2012). The Stress Response and Adolescents' Adjustment: The Impact of Child Maltreatment. Journal Youth Adolescence, 41(8), 1067-1077. https://doi.org/10.1007/s10964-012-9746-y

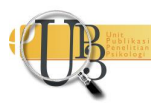


Folkman, S., \& Moskowitz, J. T. (2004). Coping: Pitfalls and Promise. Annual Review of Psychology, 55(1), 745-774. https://doi.org/10.1146/annurev.psych.55.090902.141456

Gagne, M.-Helene., \& Melancon, Claudiane. (2012). Parental Psychological Violence and Adolescent Behavioral Adjustment: The Role of Coping and Social Support. Journal of Interpersonal Violence, 28(1), 176-200. https://doi.org/10.1177/0886260512448842

Hornor, G. (2012). Emotional Maltreatment. Journal of Pediatric Health Care, 26(6), 436-442. https://doi.org/10.1016/j.pedhc.2011.05.004

Ilahi, F. R., \& Hartini, N. (2015). Hubungan antara Self-Esteem dengan Strategi Coping pada Remaja Akhir yang Mengalami Perceraian Orangtua. 04(3), 11.

KemenPPPA. (2019, May 7). Kemen PPPA Luncurkan Hasil Survei Nasional Pengalaman Hidup Anak dan $\begin{array}{llll}\text { Remaja SNPHAR } & \text { Tahun } & \text { KemenPPPA. }\end{array}$ https://www.kemenpppa.go.id/index.php/page/read/29/2123/kemen-pppa-luncurkan-hasilsurvei-nasional-pengalaman-hidup-anak-dan-remaja-snphar-tahun-2018

Lazarus, R. S., \& Folkman, S. (1984). Stress, appraisal, and coping (11. [print.]). Springer.

Lee, C., Dickson, D. A., Conley, C. S., \& Holmbeck, G. N. (2013). A closer look at self-esteem, perceived social support, and coping strategy: A prospective study of depressive symptomatology across the transition to college. Journal of Social and Clinical Psychology. https://doi.org/10.1521/jscp.2014.33.6.560

Mruk, C. J. (2006). Self-esteem research, theory, and practice: Toward a positive psychology of self-esteem (3rd ed). Springer Pub.

Mullis, R. L., \& Chapman, P. (2000). Age, Gender, and Self-Esteem Differences in Adolescent Coping Styles. The Journal of Social Psychology, 140(4), 539-541. https://doi.org/10.1080/00224540009600494

Nguyen-Feng, V. N., Baker, M. R., Merians, A. N., \& Frazier, P. A. (2017). Sexual victimization, childhood emotional abuse, and distress: Daily coping and perceived control as mediators. Journal of Counseling Psychology, 64(6), 672-683. https://doi.org/10.1037/cou0000244

Sandiana, L. A., \& Oriza, I. I. D. (2018). Peran Coping Berfokus Emosi sebagai Mediator Pada Hubungan antara Kepribadian dan Penggunaan Internet Bermasalah. Jurnal Psikologi Teori Dan Terapan. https://doi.org/10.26740/jptt.v9n1.p49-61

Santrock, J. W. (2014). Adolescence (Fifteenth edition). McGraw-Hill Education.

Sari, Y. K., \& Putra, Y. (2014). Hubungan Kejadian Verbal Abuse Orang Tua Terhadap Anak Dengan Perkembangan Kognitif Anak Usia Pra-Sekolah Di Kelurahan Tarok Dipo Wilayah Kerja Puskesmas Guguk Panjang Bukittinggi Tahun 2014. 5(2), 13. 
Shaffer, A., Yates, T. M., \& Egeland, B. R. (2009). The relation of emotional maltreatment to early adolescent competence: Developmental processes in a prospective study. Child Abuse \& Neglect, 33(1), 36-44. https://doi.org/10.1016/j.chiabu.2008.12.005

Shapero, B. G., Black, S. K., Liu, R. T., Klugman, J., Bender, R. E., Abramson, L. Y., \& Alloy, L. B. (2014). Stressful Life Events and Depression Symptoms: The Effect of Childhood Emotional Abuse on Stress Reactivity: Child Emotional Abuse and Stress Sensitization. Journal of Clinical Psychology, 70(3), 209-223. https://doi.org/10.1002/jclp.22011

Tan, G., Teo, I., Anderson, K. O., \& Jensen, M. P. (2011). Adaptive Versus Maladaptive Coping and Beliefs and Their Relation to Chronic Pain Adjustment. The Clinical Journal of Pain, 27(9), 769-774. https://doi.org/10.1097/AJP.0b013e31821d8f5a

Taylor, S. E. (2018). Health Psychology (10th edition). McGraw-Hill Education.

Wang, S., Xu, H., Zhang, S., Yang, R., Li, D., Sun, Y., Wan, Y., \& Tao, F. (2020). Linking Childhood Maltreatment and Psychological Symptoms: The Role of Social Support, Coping Styles, and SelfEsteem in Adolescents. Journal of Interpersonal Violence, 088626052091857. https://doi.org/10.1177/0886260520918571 